\title{
The PropTech Revolution: The Imperatives for Nigeria's Estate Surveying and Valuation Professionals to Catch Up or Get Left Behind
}

Vincent Uwaifiokun Aihie1

1 Department of Estate Management and Valuation, University of Benin, Nigeria.

To cite this article: Aihie, V.U. (2019). The PropTech Revolution: The Imperatives for Nigeria's Estate Surveying and Valuation Professionals to Catch Up or Get Left Behind. Journal of African Real Estate Research, 4(2), pp.56-75. DOI: 10.15641/jarer.v4i2.734.

\begin{abstract}
Information and Communication Technology (ICT) has become the bedrock of modern societies with activities being streamlined to technologically meet the needs of individuals willing to adopt it in their day-to-day lives. The emergence of ICT has influenced the activities of real estate practitioners all over the world. Despite sectoral shifts and the introduction of innovative technologies, real estate professionals have been quite conservative towards industry modernisation (whether it is information provision, transaction or management), which threatens to limit their influence in society. PropTech, or property technology, has commanded this movement by promising more efficient portfolio management, faster ways of renting accommodation and more accurate techniques of carrying out property appraisals. It has provided innovative solutions for an industry yearning for change. This paper, therefore, describes the emerging property technology industry known as PropTech. It illustrates how its development has brought changes to global perceptions of real estate. The paper also critically examines the challenges that Nigerian estate surveyors and valuers face in the advent of fast-paced information technology. It strongly proposes that professionals must learn to utilise this emerging trend or face becoming redundant in the real estate industry.
\end{abstract}

Keywords: PropTech; FinTech; Information and Communication Technology; Estate Surveryors and Valuers, Nigeria 


\section{Introduction}

Developments in Information and Communications Technology (ICT) have brought about change in almost every sphere of modern humanity. This change has been facilitated in no small way by three activities; information provision, transaction, and effective control (Baum, 2017). Real estate practice has also enjoyed the presence of ICT, particularly in developed nations. For instance, prospective investors in faraway locations can get information regarding property yields, vacancy rates and properties' initial rates of returns of a particular place with just one click online. Face to face transactions are no longer needed for real estate transactions to take place as safe and secure transfers between the buyer and seller are now possible with the advent of internet banking. Even property management is now less stressful with the introduction of technology. This is because one can keep track of several property portfolios, monitor their progress and effectively plan future expansions of properties within the organisation purview.

Furthermore, globalisation has played a major role in how the internet has improved the economics of location. A more mobile and technologically advanced workforce now means that businesses can operate anywhere. Although not every company can afford telecommuting gadgets for employees' use, many organisations have been able to develop strategies that reduce the amount of office space needed to accommodate employees. This has helped to increase efficiency among businesses by reducing the cost of leasing large spaces in expensive locations. The internet has made it possible for several transactions and activities to be carried out without the need to travel for a meeting in a specific location. The rapid growth of the internet and the need to gain a competitive advantage in business made it imperative that organisations embraced the use of ICT for productivity and strategic management (Kakabadse et al., 2005). Although various industries, such as finance, manufacturing and telecommunications, were quick to latch onto the ICT trend, the real estate industry, particularly in developing nations, have been slow to adopt this movement. For those developing nations that eventually have, growing data availability afforded them more options in terms of robust finance-grounded quantitative modelling, valuation software and property management (Baum, 2017).

As the property market is a highly heterogeneous one which lacks adequate information, the earliest application of ICT in real estate was to market real estate products to clients. For instance, marketing of properties requires concerted effort and adequate information in order to attract would-be investors (Baum, 2017). Moreso, most property market information is concealed because of heterogenous agents. This made it impossible to access, at the first instance, but with the introduction of ICT, marketing of properties has become quite easy with specific information. An example of this is the setting up of property websites that provide multiple listings services of different types of properties, their descriptions and their sale/rental prices. However, these websites still had to be run by property agents who served as intermediaries between the buyer and seller to ensure that the advertised properties were disposed off successfully. The ability to 
replace physical with virtual proximity meant that clients could easily browse the internet for property listings and complete transactions online within a short space of time (Dumpe, 2015). The relative ease with which money exchanged hands for transactions is a welcomed development. The business world, for the sake of convenience, had finally found a way to bridge the gap between finance and technology. Further research and advancements into how the finance sector could improve businesses with the aid of technology has given rise to what is today termed 'financial technology' with the acronym 'FinTech'.

It is suggested that the real estate industry needs an upgrade - a property technology or 'PropTech' upgrade (Feth \& Gruneberg, 2018). Whether it is seen as a disruption or a positive turning point in the way real estate services are rendered, most real estate professionals opine that PropTech is the way forward in terms of advancement in the real estate sector (RICS, 2019; AIC, 2019). PropTech is expanding at a rapid pace, considering the number of investors showing interest in the sector. Although still relatively new in Africa, the increased sophistication constantly being demanded of end users of real estate has led to its growth in most developed countries. PropTech promises to bring down the old crumbling wall that represents the property industry and build something entirely different with the aid of technology. Its proponents believe that PropTech brings more people to the property sphere, thereby enabling information, transaction and controlling interactions in a shared economy.

The PropTech revolution is relatively new in Nigeria, especially among estate surveyors and valuers. At present, the real estate industry has a low level of technological expertise and insufficient financial power to effectively manage large data. Therefore, one could argue that estate surveyors and valuers in Nigeria are not fully positioned to take advantage of the opportunities that the PropTech revolution offers (Oyetunji et al., 2018). This is evidenced by current rudimentary estate appraisal, management and agency practices, which have seen estate surveyors and valuers underperform in relation to their billing when providing real estate advisory services. Against this backdrop, this paper explores the history and workings of the PropTech industry, delving into the challenges facing the Nigerian real estate surveyor and valuer in the use and adoption of ICT. It explains how embracing PropTech could revolutionise the activities of these individuals, thereby making them better equipped as professionals in an ever-changing market.

\section{The PropTech Evolution}

PropTech collectively defines start-up companies which use technological innovations to provide solutions to real estate problems (Pyle et al., 2017). PropTech emerged as a culmination of years of development, finance and innovation, centred around real estate transparency, participation and understanding. This multidisciplinary development has evolved into a lucrative industry (Baum 2017; Forbes, 2018; Shaw 2018). According to Baum (2017), the first wave of PropTech, known as PropTech 1.0, took 
place around the mid-80s in the United States of America and the United Kingdom. The introduction of the personal computer and the floppy disc, which supported spreadsheet data analysis applications such as Excel, changed the world and this industry. This innovation, along with the growth of the Real Estate Investment Trust (REIT) in terms of investors, capital and advisory services, prompted growth in property ICT (Baum, 2017).

Despite these ground-breaking innovations, the storage and transfer of a large amount of data was increasingly becoming a problem, as was its accessibility to the general populace. Subsequently, the 90s brought about an increase in online trade with the mainstreaming of the internet and email (Coffman \& Odlyzko 2001). This technological expansion led to the establishment of market places, such as Craigslist, in the US and print market places, and Exchange and Mart, in the UK. These sites began the transition from print to web, selling and letting real estate alongside household goods and holidays to a growing online public. The development during this time paved the way for e-commerce as a platform and business both in real estate and finance.

Improvements in the analysis of data with the help of mainframe computers both in the US and the UK birthed property research companies such as the Investment Property Databank (IPD) (1985) and Prudential (1987). These technological innovations in research were not limited to the property investment sector as engineering, construction and management industries also benefitted from these advancements (Ojo et al., 2018). Autodesk, Yardi, Argus and CoStar were property softwares developed at this time to provide support for architecture, construction management and investmentbased decisions in real estate. As innovative as PropTech 1.0 was, it suffered an oversupply of expensive and uncollaborative real estate computer technology, which lacked adequate demand in terms of traffic (Baum, 2017).

The increase in demand for rental accommodation and the need to make sales and purchase of real estate more efficient has led to the evolution to PropTech 2.0 at the start of the 21 st century (ING, 2018). This bridged the gap between Proptech 1.0 and the public. Baum (2017) suggested that the use of technology as well as awareness on accessibility and affordability of connectivity such as mobile phones, PCs, cloud computing, Wi-Fi and 4G technology brought about change in the real estate sector. Clients are gradually dissatisfied with just buying real estate online as they demanded that these properties incorporate smart technology. This led to the introduction of PropTech 2.0. Table 1 depicts the PropTech 2.0 platform and the services rendered in different countries. 
Table 1: PropTech Platforms in Different Countries

\begin{tabular}{|c|c|c|}
\hline $\begin{array}{l}\text { PropTech } \\
\text { Venture }\end{array}$ & Country & Services \\
\hline IPD (2003) & $\begin{array}{l}\text { United } \\
\text { Kingdom }\end{array}$ & $\begin{array}{l}\text { Organises and analyses data describing the performance of commercial } \\
\text { property in the UK. }\end{array}$ \\
\hline Redfin (2004) & United States & $\begin{array}{l}\text { Online real estate portal that enables its customers to perform map- } \\
\text { based property searches. It provides value-added features such as home } \\
\text { tours (use of virtual reality). }\end{array}$ \\
\hline $\begin{array}{l}\text { Propertyfinder } \\
\text { (2005) }\end{array}$ & Dubai & $\begin{array}{l}\text { Online property portal that helps customers find properties that fit their } \\
\text { requirements. The company lists top-class properties, allowing } \\
\text { customers to browse through them and shortlist their choices easily. }\end{array}$ \\
\hline $\begin{array}{l}\text { PropertyGuru } \\
\text { (2006) }\end{array}$ & Singapore & $\begin{array}{l}\text { Online real estate portal that provides its customers with the edge they } \\
\text { require when conducting their property search and helps them make } \\
\text { well-informed decisions on property purchases, sales or letting. }\end{array}$ \\
\hline Zoopla (2008) & $\begin{array}{l}\text { United } \\
\text { Kingdom }\end{array}$ & $\begin{array}{l}\text { Provides users with access to information such as sold house prices, } \\
\text { area trends, statistics and current value estimates for domestic } \\
\text { properties in the UK. }\end{array}$ \\
\hline $\begin{array}{l}\text { PropTiger } \\
\text { (2006) }\end{array}$ & India & $\begin{array}{l}\text { Online real estate portal that helps those wanting to buy, sell or let out } \\
\text { homes on a turnkey basis. The web portal enables people to shortlist } \\
\text { their favourite homes and check attractive visuals of properties along } \\
\text { with details of the neighbourhood. PropTiger assists its customers in } \\
\text { getting home loans and completing their property registration process. }\end{array}$ \\
\hline Zumper (2011) & United States & $\begin{array}{l}\text { Online real estate portal that enables tenants to walk into a house and } \\
\text { make an offer to the landlord on the platform. }\end{array}$ \\
\hline Fangdd (2011) & China & $\begin{array}{l}\text { Online real estate portal that provides customers with a strong platform } \\
\text { where they can buy, sell and rent out properties. It allows customers to } \\
\text { search for rooms to rent in old or newly constructed properties. }\end{array}$ \\
\hline Compass (2012) & United States & $\begin{array}{l}\text { Real estate portal equipped with cutting edge technology to make } \\
\text { property search, sale and buying processes hassle-free, intelligent and } \\
\text { seamless. }\end{array}$ \\
\hline $\begin{array}{l}\text { Housing.com } \\
\text { (2012) }\end{array}$ & India & $\begin{array}{l}\text { Online real estate portal that focuses on simplifying the home search } \\
\text { process for people through its state-of-the-art web platform. The } \\
\text { company's mission is to make the process of buying, selling and letting } \\
\text { homes swift, smart and simple for all its customers. }\end{array}$ \\
\hline $\begin{array}{l}\text { Properati } \\
\text { (2012) }\end{array}$ & Argentina & $\begin{array}{l}\text { Online real estate portal that connects thousands of buyers and sellers in } \\
\text { the Latin American region in a fast and effective manner, facilitating } \\
\text { smooth deals. }\end{array}$ \\
\hline Radpad (2013) & United States & $\begin{array}{l}\text { Online real estate portal that locates houses and apartments for rent in } \\
\text { various cities and towns in the US for free. }\end{array}$ \\
\hline Nestpick (2014) & Germany & $\begin{array}{l}\text { Online real estate portal that lists furnished apartments for people to } \\
\text { buy. It provides customers with a wide selection, fast search results, } \\
\text { and the best possible prices for furnished apartments in top cities. }\end{array}$ \\
\hline $\begin{array}{l}\text { Mogoroom } \\
(2014)\end{array}$ & China & $\begin{array}{l}\text { Real estate portal that provides a rental online-to-offline }(\mathrm{O} 2 \mathrm{O}) \\
\text { platform for customers to find a house to rent quickly. It provides } \\
\text { verified property listings of landlords at highly affordable rental prices. }\end{array}$ \\
\hline
\end{tabular}




\begin{tabular}{|l|l|l|}
\hline Roomi (2015) & United States & $\begin{array}{l}\text { Online real estate portal that helps its customers find flexible and } \\
\text { affordable homes while connecting with roommates to make them feel } \\
\text { at home in a big city. }\end{array}$ \\
\hline
\end{tabular}

It is interesting to note that these start-ups/platforms have used information technology not only to provide real estate services for their clients but also to enable ease of payment through collaboration with the FinTech Industry (RICS, 2017). Despite this, these start-ups require a lot of capital in order to meet real estate information needs, and acquire technological advancements. As a result of this close interaction, the line between both FinTech and PropTech are often blurred.

\subsection{FinTech and PropTech}

The FinTech and PropTech industries are two distinct industries that have, over time, evolved with technological innovations. While the two overlap at certain intersections, they are two distinct industries. The confusion stems from the close collaboration that they share because of the funds required to transact in real estate. Real estate is a trillion-dollar asset class that affects all and is a biological and social necessity (Linklater, 2013; Dorling, 2014; Savills, 2016). With limitations such as physical deterioration, illiquidity and legal regulations, there is a need to incorporate innovations of the FinTech industry in making the real estate sector more fluid for investment purposes (Baum, 2015; 2017).

The need to cope with speed and competitiveness in real estate transactions has given rise to real estate FinTech (PWC, 2019). Research has shown that the advent of FinTech has helped to improve lending practices among real estate investors. Gaughan (2017) explains that although FinTech's new approaches to granting credit have the potential to help previously underserved and unbanked communities, it may also lead lenders to deny credit because of a lack of access to internet or an avoidance of social media. CB Insights (2012) states that real estate technology companies, including start-ups, have raised almost $\$ 6.4$ billion in funding, an attestation to the fact that undertaking an investment in property technology is very expensive and requires a lot of pooled funds.

Studies by Buchak et al. (2017) have also shown that FinTech lenders were more likely to enter the real estate market where traditional banks faced more regulatory constraints in dealing with investors. Overall, the real estate sector has lagged in other areas of financial services in its adoption of technology and given the massive size of the real estate market, it is hoped that many innovative FinTech startups will be able to address the challenges that this market faces in undergoing a digital transformation.

The World Economic Forum (2015: p.3) report on The Future of FinTech defined FinTech as: "the use of technology and innovative business models in financial services”. KPMG and CB Insights (2016) submit that although 
FinTech might be made up of several companies, it would typically include the following business niches:

Lending tech: Lending companies, primarily peer-to-peer lending platforms, as well as underwriter and lending platforms using machine learning technologies and algorithms to assess creditworthiness.

Payments/billing tech: Payments and billing tech companies provide solutions ranging from the facilitation of payment processing to subscription billing software.

Personal finance/wealth management: Tech companies that help individuals manage their bills, accounts and/or credit as well as manage their assets and investments.

Money transfer/remittance: Money transfer companies, including peer-topeer platforms, to transfer money between individuals across countries.

Blockchain/bitcoin: An emerging technology that uses distributed databases, maintained by users, to record and transfer digital assets across all participants in the network without a third party or exchange.

Institutional/capital markets tech: Companies providing tools to financial institutions such as banks, hedge funds, mutual funds or other institutional investors. These range from alternative trading systems to financial modelling and analysis software.

The current PropTech environment can be broadly divided into three specific markets, namely: Smart Real Estate, Shared Economy, and Real Estate FinTech (ING, 2018). Smart Real Estate supports real estate assets, which could be single property units or entire cities. These platforms provide information about building or urban centre performance and may directly facilitate control of building services. The goal of Smart Real Estate and smart cities is to improve the quality of life of occupants/residents. Technology is used to improve the efficiency of services and meet residents' needs while maintaining the highest level of sustainability. These international technological platforms such as Nest, Digital Realty, Equinix, and Aggreko, deliver intelligent houses that promote healthy living and energy conservation for clients (Baum, 2017).

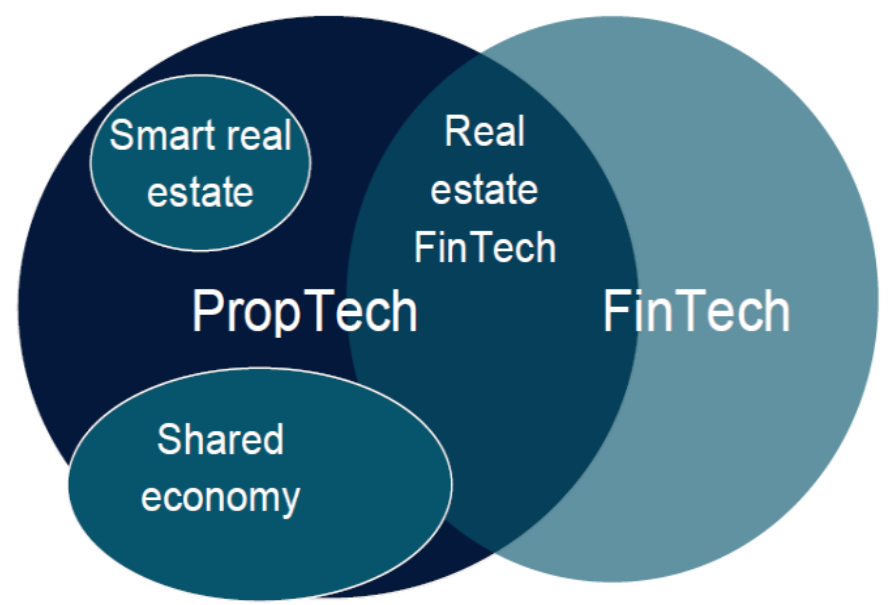

Figure 3: Real Estate FinTech: An overlap of PropTech and FinTech (Source: Baum, 2017) 
The Shared Economy facilitates the use of real estate assets. In an age of unaffordability, co-sharing of space has become the norm. This platform provides information for prospective users and sellers of such spaces. It goes a step further to ensure that rent or fee-based transactions are possible between user and seller. Some of the examples of businesses in the shared economy include Airbnb and WeWork. The American Airbnb business deals with the booking and rental of private accommodation and currently has over 4 million listings spanning more than 190 countries as of September 2017 (Airbnb Fast Fact, 2017). WeWork, which is currently valued at USD 20 billion, manages approximately 10 million square meters of office space in a bid to provide a community feel for entrepreneurs and small businesses in shared workspaces (Hempel, 2017).

Statistics show that $77 \%$ of executives indicated that the sharing economy is having the greatest impact on Airbnb business, followed by $66 \%$ coworking at WeWork business and $61 \%$ e-commerce at Amazon business (Microsoft, 2019). Not only that, $61 \%$ of commercial real estate executives indicated that their firms are using, or already trying out, online lending places, with $23 \%$ using them in a significant way (Altus, 2019). With improved technologies, such as cloud computing and Artificial Intelligence (AI), increasingly gaining relevance the Sharing Economy is a trend more businesses are looking to adopt in order to reduce the cost of using space while creating greater operational efficiencies (Moreno-Izquierdo et al., 2018). For instance, the use of machine learning is becoming increasingly frequent in companies' search for competitiveness. In many cases, AI can help companies improve their knowledge about users to optimise prices or in guiding buyers choices.

Real Estate FinTech provide direct products and services to real estate endusers, often through online and mobile channels. Companies like Zillow, Zoopla, LendInvest, OpenDoor (all technology-based platforms) help facilitate the trading of real estate assets (freehold or fee simple title, long leaseholds and shorter leases) (Baum, 2017). As highlighted earlier, real estate FinTech operates in a transparent and fluid market where data is readily available and financial regulations are put into place to curtail the excesses of overzealous investors in both the financial and real estate sector (WEF, 2015). Transparency in data has driven transaction time down and as data has become more commoditised, real estate financial markets have become more efficient.

Another current subset of the PropTech environment is a term known as ConTech. Although not part of the use, sale or lease of real estate, it is worthy of mention as it is very important to building companies. ConTech refers to the use of new technologies during construction to make the process more efficient. Robotisation and 3D printing are some of the applications in ConTech which can influence the real estate sector in areas such a project development, renovation and maintenance (ING, 2018). 


\subsection{The Professional Consensus and Influence of Proptech on the Real Estate Industry}

The 2018 survey by Teesside University and RICS to understand the challenges and opportunities of PropTech among professionals found that 95\% of real estate professionals agreed that PropTech presented more of an opportunity than a threat to the real estate surveying profession (RICS, 2019). With technological advancements in companies such as Amazon, Uber, and WeWork, the need to understand how future real estate markets will operate has united wealthy real estate 'organisation men' with younger, technology-savvy entrepreneurs. The combination of capitals allows these professionals to harness the technology needed to change the way real estate is perceived (Himanen, 2001; Baum, 2017). But what trends account for their faith in the sector? Much of it boils down to the impact of new ventures streamlining the roles of real estate professionals in a fast-changing economy. Analysis shows that a record of $\$ 12.1$ billion was invested by venture capital funds to grow the PropTech industry in 2017 (Ivens \& Barbirogli, 2018). Furthermore, a cursory glance at the delegates list of Proptech related events, such as Le marché international des professionnels de l'immobilier hosted in France, and \#PropTech2017 held in Central London, reveals that serious interest in technology is far from lacking. For example, the eight-hundred delegate list for \#PropTech2017 from over five hundred organisations included twenty-four venture capital funds; six of Europe's top ten real estate funds (representing at least $\$ 250$ billion of European real estate assets under management); and numerous start-ups with registered offices in the vicinity of Shoreditch's famous creative digital cluster, Silicon Roundabout (Foord, 2013; Shaw, 2018)

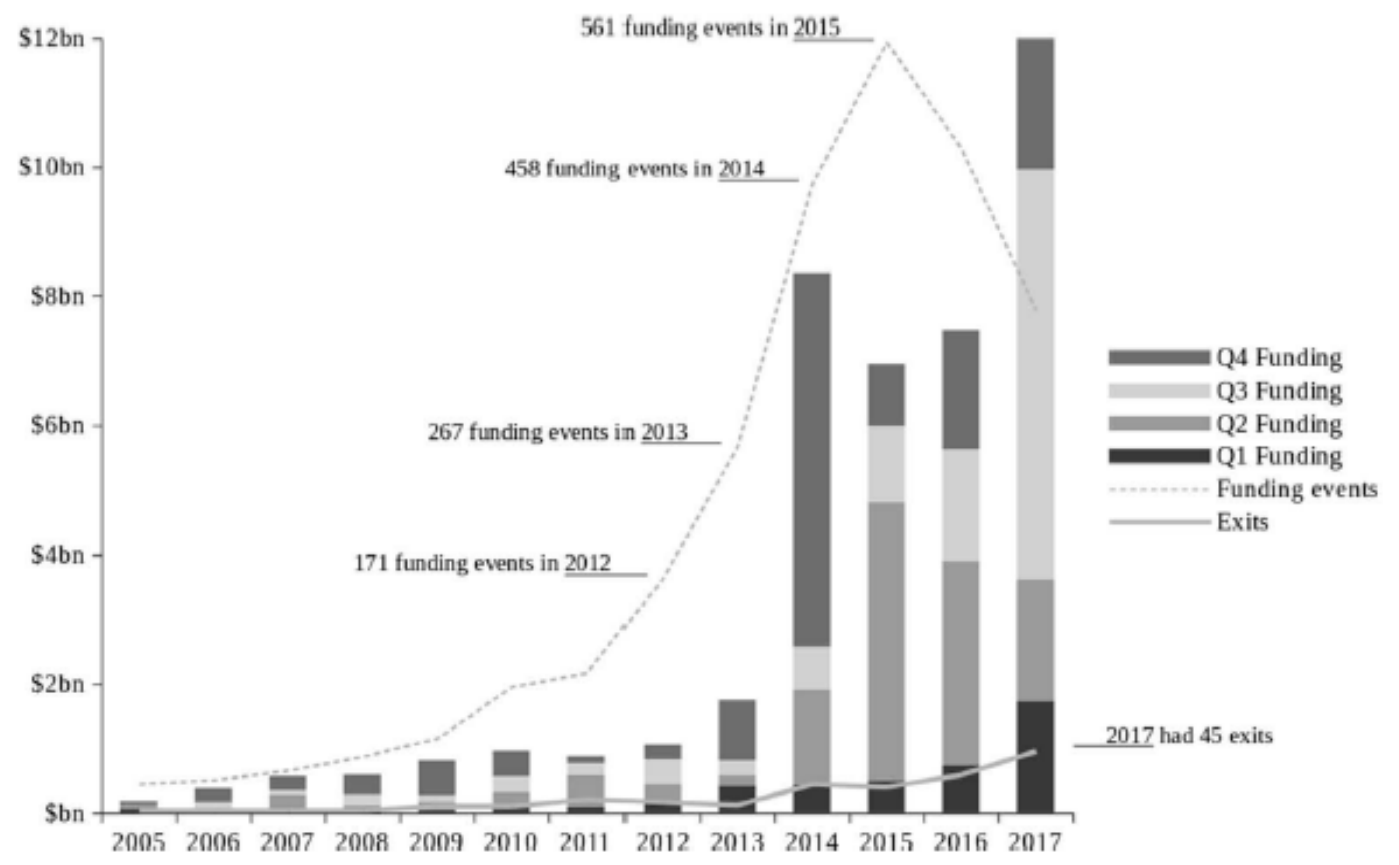

Figure 4: PropTech Investment Through Venture Capital Funds from $2005-2017$

(Soutce: Ivens \& Barbiroglio, 2018) 
The consensus among professionals is that PropTech is a smart market to invest in. Innovation in the industry is desperately needed and property technology serves to meet the demands of an increasingly digital business landscape. But what effect will this technology have? Piazolo (2018) summarised the effects of technology on real estate in the long-run to include these driving forces: increased transparency, improved efficiency, enhanced flexibility and provision of employment opportunities for individuals with new skill sets. According to Piazolo, these driving forces would be the bedrock for future developments in real estate.

\section{Estate Surveying Practice and the Proptech Industry in Nigeria}

In many ways, PropTech is seen as the innovative use of technology to solve real estate problems more efficiently and in real time. Possessing the technology is not enough to deliver on the goals of PropTech, but being able to harness large amounts of data, transform it into something useful (information) and communicate it to the final consumer (clients), to a large extent will determine how effective the PropTech industry will perform in the long-run. According to Obayan (2010), ICT has become the bedrock of modern societies with activities being streamlined to technologically meet the needs of individuals willing to adopt it in their day-to-day lives. The emergence of ICT has influenced the activities of real estate practitioners all over the world and Nigeria is no exception (Swanepool \& Tuccilino, 2003; Kakulu, 2008; Babawale, 2012). Kakulu (2008) admits that the introduction of ICT to Nigeria has brought about new ways of conducting real estate business. Although the adaptation of ICT in the real estate sector is more pronounced in developed economies, Nigerian professionals have sought ICT technology to attract international investors and improve market transparency (Oke et al., 2017). The introduction of ICT in Nigerian real estate transactions started sometime in the 21 st century with property websites publishing property information for the perusal of potential buyers (Gwin, 2004; Chukwuemeka, 2012). Its impact in Nigeria is concentrated on auctioneering and property sales. Despite this, the PropTech industry has not yet developed into a full-blown industry in Nigeria because of the lack of property data, costs involved, technical know-how, lack of transparency and instability of the market (Udobi et al., 2016; Olapede \& Olaleye, 2019).

Adeyemo et al. (2015), explore the motivating factors influencing the use of ICT in real estate practice in Minna, suggesting that external factors such as the size of real estate firm, management and overall cost of running an ICT associated practice, are limiting factors for firms. Due to the current economic situation of the country, which sees at least $70 \%$ of Nigerians living under the poverty line, professionals are finding it difficult to run their businesses or even pay their employees. Clients are not forthcoming either as only the very wealthy can afford to engage and pay for real estate services. The multiplier effect of this is that most real estate firms in Nigeria would rather spend money on essential office needs than invest in technology (Oyetunji et al., 2018). For those few firms that invest in 
technology, affordability and non-availability issues continue to remain a hindrance (Ayotunde, 2013).

Similarly, Oyetunji et al. (2018) argued that most of the real estate firms in Lagos lack the technological skills to elevate local real estate practices. They note that estate surveyors and valuers are mostly familiar with general-purpose tools like email, Microsoft Office, Excel, PowerPoint and Adobe Reader. Furthermore, the few professionals with software knowledge tend to only be proficient in AutoCAD and Revit. Thus, the knowledge and use of specialised real estate designed software like Yardi, ARGUS, IBM Tririga, Propertyware, etc. remain limited in Nigeria. The reason is not farfetched as training of real estate surveyors and valuers, both as undergraduates and graduates, touches very little on the use of technology to improve their skillsets. The training of valuers in Nigeria places a lot of emphasis on 'bricks and mortar' with very little training put into how to engineer data to perform tasks such as valuation, feasibility studies, property management and other critical functions of a contemporary property professional. A promising example is a cursory look at the National University Commission of Nigeria's curriculum of Estate Management. Most universities still make use of valuation tables to teach real estate students how to carry out valuations and the management of leases is still mainly theoretical, making the entire process of learning quite inappropriate for the realities of modern property markets.

Even in the area of property listing and advertising, where the use of ICT has been effective, Babatunde et al. (2016) reveal that banners, phone calls and emails still rank higher as methods for disseminating property information. The use of video recording by professionals in the display of properties is also minimal, given the technicalities of the medium. Thus, one can deduce that PropTech 1.0 has still not fully evolved in the Nigerian real estate practice, as property management is still carried out traditionally. Paperwork and files remain at the forefront of lease management because of the inability of professionals to make use of property management software packages, such as Yardi, Angus, or Entrata. As such, property management remains a largely manual task.

Nigeria is currently ranked number 144 out of 180 on the corruption index by Transparency International. With very weak institutions and a high rate of insecurity, in the last 10 years the country has struggled with attracting international investors. Although termed the 'giant of Africa', Nigeria has lagged behind other African countries like Kenya and South Africa in terms of foreign direct investment (FDI). FDI to West Africa declined by $15 \%$ to $\$ 9.6$ billion, largely due to Nigeria where flows plunged by $43 \%$ to $\$ 2$ billion (UNCTAD, 2019). The reason can be attributed to the corruption and lack of transparency currently experienced in the country (Adebiyi et al., 2019). Investing in PropTech is a very expensive venture, one that Africa (especially Nigeria) is not yet prepared for because of the level of poverty, corruption and political instability that reigns (Adebiyi et al, 2019). Direct foreign investment is no doubt required to hit the ground running in developing PropTech as it is quite costly to set up. The problem is that no 
investor would want to put in such huge funds in developing technology in a country with little certainty that returns on their investment will be secured. Nigeria, with a population of over 180 million people, is a country laden with opportunities, especially in the real estate sector. Unless it solves the plethora of socio-political issues currently facing the economy, it will continue to miss out on opportunities to pursue new frontiers for developing its real estate professionals.

Amidu and Aluko (2007) identify three issues that estate surveyors and valuers in Nigeria are currently facing in the area of valuation; inaccuracy, bias and client influence. This is because most valuers are only apt in traditional methods of valuation that do not require as much ICT and quantitative knowledge as those of the advanced methods (Pagourtzi et al., 2003). The consequence of this is that valuers are not able to accurately determine property values which capture the ever-changing price volatility of the contemporary property market (Hui et al., 2009). Computer-Aided Valuation (CAV) is a popular solution to this issue. Although the approaches of valuation remain universal, the ability to use CAVs accurately is still dependent on the skill and technical know-how of the valuer (Ibrahim et al., 2005; Tretton, 2007).

Given these contextual challenges, it's important to also note the other factors that impact the technological adoptation in Nigeria's property sector. Eyenubo (2015) highlights that the recapitalisation of the Nigerian banking sector in June of 2004, has seen the financial sector leverage considerable capital and improve its ICT technology. As a result, more businesses in Nigeria, including start-ups, have been established and collaborated with the financial sector to increase the value of their services (KPMG, 2016). Despite this positive (collaborative and technological) trend across various Nigerian sectors, the real estate and financial sector have failed to materialise joint service delivery. An instance of this is a case where issues of mortgage financing and housing affordability persist in Nigeria as many property professionals have been seen to exploit the financial sector for personal gain rather than seek public solutions (Ndubueze, 2009).

\section{Problems Militating the Adoption of Proptech by the Estate Surveying and Valuation Profession in Nigeria and its Implications}

Real estate professionals in most countries are slow to accept changes that might affect their inherent roles (KPMG, 2018). Valuers in Nigeria are no exception. Unlike the financial world which readily embraces change, the property sector and its professionals are typically quite conservative, hence the reluctance to fully accept ICT as an integral part of the services they render. While the financial sector in Nigeria continues to grow with the aid of technological advancement, the real estate sector and its professionals seem to be lagging. In a developing country like Nigeria, the factors militating the growth of technology in the real estate sector are numerous and, as mentioned and alluded to earlier, they hinder Proptech adoption in the Nigerian property sector. This section focuses on factors such as the cost 
and maintenance involved, technical know-how, lack of transparency and the instability of the market. While all these factors are interlinked in reality, their individual impact are worth noting.

Various authors highlight several barriers to the deployment of ICT in real estate firms in Lagos state. Out of these (Babajide et al., 2018; Oyetunji et al., 2018), stated that inability to keep up with rapid changes in ICT technologies, lack of technical know-how and high cost of technological investment are the major barriers at the forefront. These remain significant because of the inadequate training real estate students in tertiary institutions are exposed to in the area of technology, the high rate of poverty among the citizenry and the political/economic instability currently experienced in the country today. Another important factor that could make it significant can be attributed to insufficient motivation to spend more on current technologies due to the erratic power supply bedevilling the nation (Oyetunji et al., 2018).

It would be unfair to say there are no valuers in Nigeria trying to add value to their services through technology, but their numbers are few and innovation in the profession is still lacking. Most practising valuers and viable corporate firms in the country would rather embrace traditional methods than learn to master new technology. This is due to the lack of technical knowledge among older professionals. This highlights that technology and investment vehicles for investment in PropTech are not enough and there needs to be a critical mass of appropriate skills to enable the unlocking of the potential of these innovations in the Nigerian real estate sector. The younger generation of valuers are more likely to challenge the status quo but unfortunately, younger valuers do not have the capital to venture into the PropTech industry.

Oni (2013) concludes that most valuers show a lack of commitment in embracing ICT as a result of certain factors ranging from high costs of acquisition, training and maintenance charges paid for by the use of this software. Information obtained from phone calls that were put across to staff of ARGUS, (a real estate software company which specialises in real estate investment analysis and development with headquarters in the United States of America) offers its basic package to real estate professionals at $\$ 600$ a month or $\$ 2600$ annually. At today's exchange rate $(\$ 1=\$ 360.00)$ this amounts to $\$ 216,000$ monthly or $\$ 936,000$ annually (XE, 2019). The real estate sector contracted by $-3.85 \%$ in Q4 2018 from 2.68\% in Q3 2018 and $5.92 \%$ in Q4 2017. On an annual basis, the nominal growth rate for real estate services in contribution to the national GDP was $0.48 \%$ in 2018, lower than the $3.01 \%$ recorded in 2017 (NBS, 2019). This evidence supports how a contracting real estate sector is unable to make largescale investments in technology when the sector is experiencing pervasive austerity and as a result, professionals are becoming risk averse. If real estate professionals in Nigeria cannot benefit from the technological innovations of PropTech, such as the use of real estate software because of a lack of affordability, it begs the question of how productive their practice would be, both now and in the future. 
Although a few valuers possess the appropriate skillset to apply ICT in real estate, the emphasis on direct human contact in conducting real estate business in Nigeria has meant that the valuer has come to be regarded as a 'low tech, high touch' professional (Ayotunde, 2013: p.6). As a result of this belief, there is a strong emphasis on ability to express oneself qualitatively rather than quantitatively in this profession. The multiplier effect of this is that there are more valuers prone to carrying out valuations/rendering real estate services in a manner that is quite localised and unsophisticated. Even at the university level, undergraduate students of Estate Management are hardly exposed to any software technology that is relevant to their field of study. A study carried out by Egbenta (2015) shows that Estate Management graduates have very low to average employability skills, especially in the area of ICT. The effect of this is that these graduates, who eventually become valuers, cannot understand or manipulate the most basic of computer software to execute tasks. A good example is the modelling of investment cash flows with Excel. This involves estimating the value of an investment based on projections of its future cash flows. Excel can be used to work out the present value of a particular real estate portfolio investment and, at a glance, provide a basis for an investor to make informed decision on whether to proceed with a project or abandon it. The use of Excel also helps eliminate the errors that can be encountered when calculations involving summations are carried out manually.

It is also instructive to note that the Nigerian Institution of Estate Surveyors and Valuers (NIESV) currently has 15 faculties set up for the professional development of its members, yet not a single faculty is strategically dedicated to the technological advancements of its constituents (NIESV, 2019). The implication of this is that many of the registered valuers, especially those of the older generation heading these various faculties, are not skilled in applying technology to their crafts as professionals. These faculties are, at best, dormant and lacking the much-needed technological expertise to fine tune the skill sets of valuers. This puts the average Nigerian valuer at a disadvantage when compared to his foreign counterpart as the latter, armed with advanced computer-based skills, is able to provide realtime solutions to the most complex of real estate problems. Another consequence of the non-existence of a faculty dedicated to the technological development of valuers is the fact that as of today, the NIESV cannot showcase a data bank which investors both locally and internationally can rely on to easily make informed investment decisions.

The performance of real estate firms in the country still remains limited to the knowledge and decision-making ability of the principal partner of the firm. Oloke et al. (2013) attribute the bane of partnership formation primarily to dishonesty, undue family interference, and disagreement, which has made the sole proprietorship form of business a preferred choice amongst real estate firms in Nigeria. The sole proprietorship form of business practice by real estate firms in the country has been in vogue since the early 1970s when NIESV was formed. Out of the 915 registered real estate firms in Nigeria today, at least $85 \%$ of them are a sole proprietorship 
form of businesses while the remaining $15 \%$ are some sort of partnership (NIESV, 2019). These sole proprietorship real estate firms are headed by a principal who is responsible for making all the decisions in the firm and provides the finances for the day to day running of the firm. These 'sole owner' real estate firms, at best, operate on a very local scale and do not have the financial muscle to engage in PropTech for the benefit of their firms.

In addition to the economic struggles that limit the adoption of technology, there are also structural issues that create further obstacles (World Economic Forum, 2018). These can be seen as political and external to the real estate sector itself, leading to scepticism amongst valuers in investing into technological advancement in the property sector. The implications of this to the estate surveying valuation profession in Nigeria are dire, and the effects are already being felt with the incursion of non-professionals into brokerage and valuation aspects of the profession. Also, the external factors impeding the growth of technology speak more broadly to investor sentiment in the nation as a whole, which is negative and unwilling to risk investment. This has knock-on effects to the adoption of tech in real estate as investors are hesitant to take a gamble on untested technologies in an unstable context.

\section{The Way Forward}

In order to bridge this technological knowledge gap exhibited by valuers in the country, it is recommended that valuers rigorously pursue continuous education and personal development. Estate Management university curriculums at undergraduate and postgraduate levels should be developed in such a way that students are proficient in real estate related software applications before they graduate. NIESV should also encourage aspiring valuers to be more innovative with the critical analysis they produce. This could come by way of displaying mastery in the use of technological softwares to proffer solutions to real estate problems, whether it is rendering real estate services to a client or helping improve the skill set of a valuer.

The traditional way of running real estate firms internally in Nigeria must be re-evaluated both by the NIESV and the Estate Surveyors and Valuers Registration Board of Nigeria (ESVARBON). The sole proprietorship form of estate practice, although once thought to be entrepreneurial and quite promising, has not been dynamic enough to encourage growth amongst young valuers in the country today. Thus, in re-evaluating the industry, firms must implement sustainable practices of management, recruitment, investment and knowledge production.

Dominant ideological practices which promote ICT and collaboration should be embraced by Nigerian valuers, given its emphasis on innovation and sustainability. NIESV must change its development faculties to ensure technological trends are accessible to Nigerian practising professionals. Furthermore, NIESV must start welcoming professionals with different skillsets into its folds. Collaboration between the NIESV and technology 
experts is paramount in preparing the real estate profession for the challenges of the digital journey ahead. As the digital threat to the estate surveying valuation professional grows, the onus is on estate surveyors and valuers in Nigeria to stand up and be counted in terms of technological advancement or lose out to more innovative professionals

\section{Conclusion}

This study has investigated the need for Nigerian real estate professionals to key into PropTech as a way of bridging the technological gap that may negatively impact real estate practice. This paper looked into factors militating the growth and development of technological advancement, the reasons why most firms could not afford investing in technological development, and the way forward, so that they will not be left behind by their counterparts in developed economies. Although the revolution of PropTech is progressing in European nations, Nigerian appraisers must key into the opportunities that surround the application of such technologies. Professionals in the real estate sector will have to adapt to new technologies sooner or later, and those who embrace change will benefit the most. As with any industry, change is necessary for growth, and those who accept and assimilate PropTech into their current practices stand to gain from it. Whether real estate professionals in Nigeria are ready to key into the prospects of the PropTech industry is yet to be seen, but one thing is certain, the 'PropTech Ship' has set sail, and there is no stopping it.

\section{References}

Adebiyi, J., Sanni, G. \& Oyetunji, A. (2019). Assessment of Political Risk Factors Influencing the Corporate Performance of Multinationals Construction Companies in Northeastern Nigeria. Global Journal of Business, Economics and Management: Current Issues, 9(2), pp.6375. https://doi.org/10.18844/gjbem.v9i2.4232.

Adeyemo, A.A., Kemiki, O.A., Adama, U.J. \& Ayoola, A.B. (2015). Factors Influencing the Use of Information and Communication Technology in Real Estate Practice in Minna. ATBU Journal of Environmental Technology, 8(2), pp.1-10.

Appraisal Institute of Canada, (2019). A Sea Change is Upon Us. Canadian Evaluation, 63(2).

Airbnb Fast Fact (2017). Airbnb Newsroom. Online. Available at: https://press.airbnb.com/en-ca/fast-facts/ (Accessed: September 17, 2019).

Altus Group (2019). The Innovation Opportunity in Commercial Real Estate: A Shift in PropTech Adoption and Investment. Online. Available at: https://www.peievents.com/en/wpcontent/uploads/2018/12/CRE-Innovation-Report-2019.pdf (Accessed October 4, 2019).

Amidu, A.R. \& Aluko, B.T. (2007). Client influence in residential property valuations: an empirical study. Property Management, 25(5), pp.447-461. 
Ayotunde Olawande Oni. (2013). Digital divide - A Challenge to the Real Estate Practice in Nigeria? Property Management, 31(1), pp.22 - 38.

Babatunde, T.O., Ajayi, C.A. \& Oladokun, T.T. (2016). The Use of Social Media in Real Estate Transactions in Lagos, Nigeria. 9th CIDB Postgraduate Conference Cape Town, Department of Construction Economics and Management, University of Cape Town, Vol.37, 1-4 February.

Babajide, O., Oyetunji, B.O \& Oyetunji, A.K. (2018). Barriers to ICT Deployment in the Nigerian Real Estate Practice. FULafia Journal of Science \& Technology. 4(2).

Babawale, G. K. (2012). Paradigm Shift in Investment Property Valuation Theory and Practice: Nigerian Practitioner's Response. Mediterranean Journal of Social Sciences. 3(3), pp.217-228.

Baum, A. (2015). Real Estate Investment: A Strategic Approach (3rd ed.). Oxford: Routledge.

Baum, A. (2017). PropTech 3.0: the future of real estate. Online. Available at:http://eureka.sbs.ox.ac.uk/6485/1/122037\%20PropTech_FINAL.p df. Said Business School.

Buchak, G., Gregor M., Tomasz P. \& Amit S. (2017). Fintech, Regulatory Arbitrage, and the Rise of Shadow Banks. National Bureau of Economic Research Working Paper Series, no. 23288. Online. Available at: http://www.nber.org/papers/w23288

Chukwuemeka, C.C. (2012). Application of Technology in Business: Developing a Web-Based Real-Estate Information System for the Nigerian Market. An unpublished dissertation submitted to the University of Manchester.

Coffman, K.G. \& Odlyzko A.M. (2001). The Size and Growth Rate of the Internet, Optical Fiber Telecommunications IV Journal, July.

Dorling, D. (2014). All that is Solid: The Great Housing Disaster. London: Allen Lane.

Dumpe, M. (2015). Online Marketing Issues of Real Estate Companies: A Case of Latvia. Baltic Journal of Real Estate Economics and Construction Management. 3(1), pp.130-139.

Egbenta, I.R., (2015). Employability Skills among Graduates of Estate Management in Nigeria. Journal of Education and Practice. 6(31).

Eyenubo, A.S. (2015). Bank Recapitalization and Economic Prosperity: A Case of Nigeria Banking Industry. Research Journal of Finance and Accounting, (17), pp.26-29.

Feth, M. \& Gruneberg, H. (2018). Proptech - The Real Estate Industry in Transition. SSRN Electronic Journal.

Foord, Jo. (2013). The New Boomtown? Creative City to Tech City in East London. Cities, 33, pp.51-60.

Gaughan, M. (2017). FinTech and the Liberation of the Community Reinvestment Act Marketplace. Cityscape: A Journal of Policy Development and Research, 19(2).

Hempel, J. (2017). https://www.wired.com/story/this-is-why-weworkthinks-its-worth-20-billion/. Retrieved September 17, 2017

Himanen P. (2001) The Hacker Ethic: a radical approach to the philosophy of business, New York: Random House 
Forbes. (2018). 3 PropTech Investors Talk Trends, Game-Changers And The Future Of Real Estate. Online. Available at: https://www.forbes.com/sites/alyyale/2018/09/13/3-proptechinvestors-talk-trends-game-changers-the-future-of-realestate/\#45aa9a591812 (Accessed: August 31, 2019).

Hui, E.C.M., Lau, O.M.F. \& Lo, T.K.K. (2009). Deciphering Real Estate Investment Decisions Through Fuzzy Logic Systems. Property Management, 27(3), pp.163-177.

Ibrahim, M.F., Cheng, F.J. \& Eng, K.H. (2005). Automated Valuation Model: An Application to the Public Housing Resale Market in Singapore. Property Management, 23(5), pp.357 373.

ING (2018). Technology in the Real Estate Sector. Online. Available at: https://think.ing.com/uploads/reports/ING_EBZ_PropTechTechnlogy_in_the_real_estate_sector-June_2018_tcm162148619.pdf (Accessed: August 31, 2019).

Ivens, F. \& Barbiroglio, E. (2018). Global Funding for Proptech Sector grew to $£ 8.5$ bn in 2017. Property Week. Online. Available at: https://www.propertyweek.com/finance/globalfunding-for-proptechsector-grew-to-85bn-in-2017/5096012.article (Accessed: August 31, 2019).

Kakabadse, N., Kakabadse, A. \& Kouzmin, A. (2003). Reviewing the Knowledge Management Literature: Towards a Taxonomy. Journal of Knowledge Management, 7(4):75-91

Kakulu, I.I. (2003). Computerized Approach to Real Estate Practice in Nigeria. IBK Publication, Port Harcourt, Nigeria.

Kakulu, I.I. (2008). Capacity Building for Automated Land Information System in Nigeria. Paper presented at the strategic integration generation, FIG working week, Stockholm, Sweden.

KPMG and CB Insights (2016). The Pulse of Fintech, Q1 of 2016. https://assets.kpmg/content/dam/kpmg/pdf/2016/05/the-pulse-of-

fintech.pdf Available at: www.kpmg.com/fintechpulse and www.cbinsights.com (accessed August 31, 2019).

KPMG (2016): FinTech in Nigeria- Understanding the Value Proposition, https://assets.kpmg/content/dam/kpmg/ng/pdf/ng-fintech-in-nigeriaunderstanding-the-value-proposition.pdf available at: www.KPMG.com/ng (accessed August 31, 2019)

Linklater, A. (2013). Owning the Earth: The Transforming History of Land ownership. New York: Bloomsbury.

McAusland, C. (2010). Globalization's Direct and Indirect Effects on the Environment. Globalization, Transport and the Environment, ed. Nils A. Braathen (OECD), 31-54.

Moreno-Izquierdo, L., Egorova, G., Peretó-Rovira, A., Más-Ferrando, A. (2018). Exploring the Use of Artificial Intelligence in Price Maximisation in the Tourism Sector: Its Application in the Case of Airbnb in the Valencian Community. Journal of Regional Research, 42:113-128

Morozov, E. (2013). To save everything, click here. London: Allen Lane.

National Bureau of Statistics (2019). Nigerian Gross Domestic Product Report (Q4 \& Full Year 2018) available at www.nigerianstat.gov.ng (accessed September 20, 2019) 
Ndubueze, O. J. (2009). Urban Housing Affordability and Housing Policy Dilemmas in Nigeria, Unpublished $\mathrm{PhD}$ Thesis, Birmingham: University of Birmingham.

NIESV (2019) website available at https://www.niesv.org.ng/ (accessed August 31, 2019)

Nils K., Eija-leena K.,and Carmen adriana M-B (2017). Big Data in Real Estate? From Manual Appraisal to Automated Valuation. Journal of Portfolio Management, Special Real Estate Issue. pp.202-211

Ojo, B., Oyetunji, B.O \& Oyetunji, A.K. (2018). Barriers to ICT Deployment in the Nigerian Real Estate Practice. FULafia Journal of Science \& Technology. 4(2):57-65

Oladapo, A.A. (2007). An Investigation into the use of ICT in the Nigerian Construction Industry. ITcon, Special Issue, Construction Information Technology in Emerging Economies, 12:261-266.

Olapade, D. \& Olaleye, A. (2019). Factors Affecting Accessibility to Property Data in an Opaque Market. Property Management, 37(1), pp.82-96. https://doi.org/10.1108/PM-01-2017-0004

Oladokun, T. \& Ogunbiyi, J. (2018). "External Factors Critical to Success in the Business of Estate Surveying Firms in Lagos State, Nigeria". Journal of Facilities Management, 16(2):142-156.

Oloke, O.C, Clement, Ijasan, K.C. \& Oyedele, B.J. (2013). Performance Assessment of Partnership Estate Surveying and Valuation Firms in Lagos State, Nigeria. Mediterranean Journal of Social Sciences. 4(13):489-497

Oyediran, O.S. and Odusami, K.T. (2005). A Study of Computer Usage by Nigerian Quantity Surveyors. ITcon, 10:291-303, available at: www.itcon.org/2005/20 (accessed July 07, 2019).

Oyetunji, A.K., Ojo, B. \& Oyetunji-Olakunmi, B. (2018) Factors Influencing the Deployment of ICT in Nigerian Real Estate Practice. Journal of African Real Estate Research, 1(1):1-24

Oyetunji, B.O, Babajide, O., \& Oyetunji, A.K (2018). ICT Utilization Status and Challenges in the Nigerian Real Estate. Practice Journal of Information Science, Systems and Technology, 2(2):28-39.

Pagourtzi, E., Assimakopoulos, V., Hatzichristos, T., \& French, N. (2003). Real Estate Appraisal: A Review of Valuation Methods. Journal of Property Investment \& Finance, 21(4), 383 - 401.

Piazolo, D. (2018). The Driving Forces Behind Real Estate Digitalization. Presentation ARES 2018. THM Technische Hochschule Mittelhessen Germany.

PwC (2019). Emerging Trends in Real Estate. A publication from Urban Land Institute. https://www.pwc.com/jg/en/publications/etre_us_2019_report.pdf available at www.pwc.com (accessed October 10, 2019).

Pyle, A., Grunewald, D. and Wright, N. (2017), "Bridging The Gap. How the Real Estate Sector can Engage with PropTech to bring the Built and Digital Environments Together", pp. 1-24, https://assets.kpmg.com/content/dam/kpmg/uk/pdf/2017/11/proptech -bridging-the-gap.pdf. (accessed August 31, 2019).

Royal Institution of Chartered Surveyors (2017). The Future of Valuations: The Relevance of Real Estate Valuations for Institutional Investors 
and Banks-views from an European Expert Group. www.rics.org/insight (accessed August 31, 2019)

Royal Institution of Chartered Surveyors (2019). The Future of Cities: Positivity or Pessimism on PropTech. www.rics.org/journals (accessed August 31, 2019)

Savills. (2016). World real estate accounts for $60 \%$ of all mainstream assets. Retrieved: http://www.savills.com/_news/article/105347/1985590/1/2016/world-real-estate-accounts-for-60-of-all-mainstream-assets (accessed August 31, 2019)

Shaw, J. (2018). Platform Real Estate: theory and practice of new urban real estate markets, Urban Geography, pp. 1-28.

Swanepool,S. and Tuccillo, J. (2003). Real Estate Confronts Profitability. Real Estate White Paper. http://www.swanepool.com/publication/ (accessed August 31, 2019)

Tretton, D. (2007). Where is the World of Property Valuation for Taxation Purposes Going? Journal of Property Investment \&Finance, 25(5), 482-514.

Udobi, A. N., Kalu, I. U. \& Elekwachi, C. M. (2016). Challenges of International Real Estate Investment in an Emerging Economy: The Nigerian Experience. Civil and Environmental Research Journal, $8: 3$.

United Nations Conference on Trade and Development (2019). World Investment Report 2019. https://www.franceinvest.eu/wpcontent/uploads/France-Invest-Hebdo/064/World-Invesment-Report2019.pdf (accessed October 4, 2019)

XECurrencyConverter(2019)https://www.xe.com/currencyconverter/convert $\angle$ ? Amount $=1 \&$ From $=$ USD \&To=NGN (accessed October 4, 2019)

World Economic Forum (2015). The Future of FinTech: A Paradigm Shift in Small Business Finance, World Economic Forum. http://www3.weforum.org/docs/IP/2015/FS/GAC15_The_Future_of _FinTech_Paradigm_Shift_Small_Business_Finance_report_2015.p df (accessed August 31, 2019)

World Economic Forum (2018). The Inclusive Development Index 2018 Summary and Data Highlights, World Economic Forum. http://www3.weforum.org/docs/WEF_Forum_IncGrwth_2018.pdf (accessed August 31, 2019)

World Bank (2017). Atlas of Sustainable Development Goals: From World Development Indicators. World Bank Atlas https://openknowledge.worldbank.org/handle/10986/26306 (accessed August 31, 2019) 